\title{
Evaluation of genotoxicity of Pseudevernia furfuracea (L.) Zopf by RAPD analysis
}

\author{
S. Aras ${ }^{1}$, T. Beyaztaş ${ }^{1}$, D. Cansaran-Duman ${ }^{2}$ and E. Gökçe-Gündüzer ${ }^{1}$ \\ ${ }^{1}$ Biotechnology Section, Department of Biology, Faculty of Science, \\ University of Ankara, Tandogan, Ankara, Turkey \\ ${ }^{2}$ Drug and Cosmetics Research Department Laboratories, \\ Refik Saydam National Public Health Agency, Sihhıye, Ankara, Turkey \\ Corresponding author: S. Aras \\ E-mail: aras@science.ankara.edu.tr
}

Genet. Mol. Res. 10 (4): 3760-3770 (2011)

Received May 19, 2011

Accepted October 5, 2011

Published December 15, 2011

DOI http://dx.doi.org/10.4238/2011.December.15.4

\begin{abstract}
We investigated the suitability and applicability of Pseudevernia furfuracea (L.) Zopf for environmental genotoxicity assessment. $P$. furfuracea lichen specimens were collected from 10 different Pinus species, in every $5 \mathrm{~km}$, starting from around an ironsteel factory located in the central area of Karabük Province up to Yenice Forest. The impact of the pollution sources such as iron-steel factory, roads and railroads, industry, heavy traffic, and waste treatment plants on the heavy metal accumulation in lichens is known. DNA changes in $P$. furfuracea samples exposed naturally to various polluted sites were analyzed by RAPD to know the influence of the environmental pollution on the hereditary material of the organisms. Twenty-five different primers were tested and 10 yielded clear and reproducible bands. The present study shows the suitability of the lichen samples for the detection of genotoxicity and also provides information about the level of potential genotoxic agents around a steel mill.
\end{abstract}

Key words: Pseudevernia furfuracea; RAPD; Genotoxicity 


\section{INTRODUCTION}

Lichens are associations of fungi and green algae or cyanobacteria, which are significant for studies monitoring atmospheric heavy metal pollution. Lichens are capable of absorbing elements directly from the atmosphere far above their need and accumulating them in their tissues. Because of their great tolerance to radical environmental conditions they grow in a wide geographical distribution. They benefit from atmospheric deposition as a basic source of minerals and they are perennial organisms. Their morphologies do not show changes according to climate. These features of lichens rank them among the best bioindicators of air pollution (Ölmez et al., 1985; Bargagli, 1995; Garty et al., 1997).

In atmospheric heavy metal pollution studies, generally two basic methods are applied: either physiological effects of heavy metal accumulation are analyzed in the species that live close to the pollutants or clean lichen samples are collected and exposed to the polluted areas to detect physiological responses and bioabsorption, the latter method known as a transplant study. The lichen species which live close to the polluted areas absorb and accumulate metal pollutants for years because of their perennial characteristics. Therefore determining bioaccumulation and physiological effects of lichens exposed to natural habitats provide more realistic data about the biological effects of pollutants than transplant studies conducted in the region. The frequently used bag technique has both advantages and disadvantages. While the ability to monitor the increase in the amounts of pollutants and to know the duration of exposure are advantages, absorption differences due to climatic and environmental changes, lichen material loss because of precipitation, wind and also lack of standardization are regarded as the disadvantages of this technique (Fernandez et al., 2000).

Lichens are widely used in biomonitoring studies of air pollution, either as bioindicators of air quality or as bioaccumulators of atmospheric deposition. Lichens provide a number of advantages in biomonitoring over instrumental monitoring since they can accumulate most elements, including heavy metals, and are usable at low expense. In contrast to physical and chemical methods, biological methods allow the direct assessment of the genotoxic potential of air stressors. These advantages feature biological data for the estimation of environmental impact and the potential impact on other organisms, including humans (Piraino et al., 2006; Aras et al., 2010).

The evaluation of early-warning responses at the subcellular level may be very useful for the prevention of long-term ecological damage (Kalpaxis et al., 2004), and inducement of DNA damage is considered to be one of the earliest signs of environmental disturbance. Moreover, as a biomarker endpoint, it gains importance considering the possible consequences that genotoxicity can have on organisms and populations inhabiting contaminated environments (Depledge, 1998; Belfiore and Anderson, 2001; Jha, 2004; Stambuk et al., 2009).

Heavy metals, including essential ones, are genotoxic agents after exposure to certain dosages or for long periods. They cause damage like additions, deletions and point mutations on nucleic acids. Some of this damage might be repaired by the mutation repair mechanisms but some of it might remain. In recent studies, it has been shown that changes in DNA due to genotoxic agents could be analyzed with DNA fingerprinting methods like RAPD (Random amplified polymorphic DNA) and Amplified Fragment Length Polymorphism (AFLP) (Labra et al., 2003; Liu et al., 2005). Lichens have been used in bioindication of genotoxic heavy metals for a long time. However in these studies, physiological parameters are used to evaluate environmental damage to lichens such as photosynthesis, 
respiration, chlorophyll content and degradation, membrane integrity and stress-ethylene production (Liu et al., 2005). On the other hand, although lichens are considered very good bioindicators of air pollution and numerous studies have been conducted about their heavy metal accumulation capacity, only two studies conducted in our laboratory have been published to our knowledge, about their putative genotoxicity indicator capacity (Aras et al., 2010; Cansaran-Duman et al., 2011).

The present investigation involved the collection of ten P. furfuracea (L.) Zopf samples growing on Pinus sp. from 10 sites in and around the Karabük Steel Mill area, Karabük, Turkey and aimed to show genotoxic effects of various contaminants including heavy metals on P. furfuracea (L.) Zopf qualitatively by RAPD analysis. Results of the current research would provide an idea about assessment of the genotoxic potential of air pollutants around the Karabük Steel Mill in Karabük, Turkey which might provide insights for future genotoxicity monitoring studies with lichens in polluted areas.

\section{MATERIAL AND METHODS}

\section{Area of study}

The area of study is located between $40^{\circ} 59^{\prime} 03^{\prime \prime}-41^{\circ} 00^{\prime} 00^{\prime \prime} \mathrm{N}$, and $32^{\circ} 05^{\prime} 55^{\prime \prime}-$ $32^{\circ} 18^{\prime} 15^{\prime \prime} \mathrm{E}$ in the western part of the Black Sea region, and belongs to district of Yenice in the province of Karabük. From the Yenice Forest to the Karabük Steel Mill, 10 samples of $P$. furfuracea (L.) Zopf were collected every $5 \mathrm{~km}$ (Table 1, Figure 1). The control sample collected from the Yenice Forest was not exposed to any kind of contamination. Yenice Forest is noted for its humid and rainy climate. The annual mean temperature is $8.8^{\circ} \mathrm{C}$, relative humidity is $76.2 \%$ and total precipitation is about $1200 \mathrm{~mm}$. Numerous industrial activities, such as coal, iron, steel and cement, and an active intercity highway are present in the area. Besides, a railroad for shipping of coal and raw materials has existed in Karabük for many years. The regions of activity indicated are very close to the city center of Karabük, where coal is generally consumed instead of natural gas during the winter. According to the local environmental unit parameters, $\mathrm{SO}_{2}$ and $\mathrm{PM}_{10}$ contamination increases to harmful levels in wintertime. A rich and large forest ecosystem in terms of species is also present in the city, which must be protected according to the World Wildlife Fund (WWF).

\begin{tabular}{|c|c|c|c|}
\hline Locality No. & GPS co-ordinates & Locality name & Altitude (m) \\
\hline 1 & $44^{\circ} 62^{\prime} \mathrm{N}, 45^{\circ} 73^{\prime} \mathrm{E}$ & Karabük, Yenice, Kuzdağ district & 1125 \\
\hline 2 & $41^{\circ} 15^{\prime} \mathrm{N}, 32^{\circ} 35^{\prime} \mathrm{E}$ & Karabük, Yenice, Kabaklı kaya & 1140 \\
\hline 3 & $41^{\circ} 13^{\prime} \mathrm{N}, 32^{\circ} 28^{\prime} \mathrm{E}$ & Karabük, Yenice, vicinity of Hamzakıran district & 1140 \\
\hline 4 & $41^{\circ} 14^{\prime} \mathrm{N}, 32^{\circ} 35^{\prime} \mathrm{E}$ & Karabük, Yenice, Dikilitaş & 1125 \\
\hline 5 & $41^{\circ} 12^{\prime} \mathrm{N}, 32^{\circ} 25^{\prime} \mathrm{E}$ & Karabük, Yenice, vicinity of Kuzdere, Hamdioğlu district & 1400 \\
\hline 6 & $41^{\circ} 15^{\prime} \mathrm{N}, 32^{\circ} 34^{\prime} \mathrm{E}$ & Karabük, Yenice, north of Yalnızca plateau & 1200 \\
\hline 7 & $41^{\circ} 11^{\prime} \mathrm{N}, 32^{\circ} 27^{\prime} \mathrm{E}$ & Karabük, Yenice, Acısu Center & 1375 \\
\hline 8 & $41^{\circ} 14^{\prime} \mathrm{N}, 32^{\circ} 33^{\prime} \mathrm{E}$ & Karabük, Yenice, Kazancıoğlu district & 1750 \\
\hline 9 & $41^{\circ} 12^{\prime} \mathrm{N}, 32^{\circ} 29^{\prime} \mathrm{E}$ & Karabük, Yenice, Hacıömerler district & 1380 \\
\hline 10 & $41^{\circ} 12^{\prime} \mathrm{N}, 32^{\circ} 29^{\prime} \mathrm{E}$ & Karabük, Yenice, Kızılgöz kayası & 1385 \\
\hline $11^{* *}$ & $41^{\circ} 10^{\prime} \mathrm{N}, 32^{\circ} 24^{\prime} \mathrm{E}$ & Karabük, Yenice, vicinity of Cami district & 1100 \\
\hline
\end{tabular}




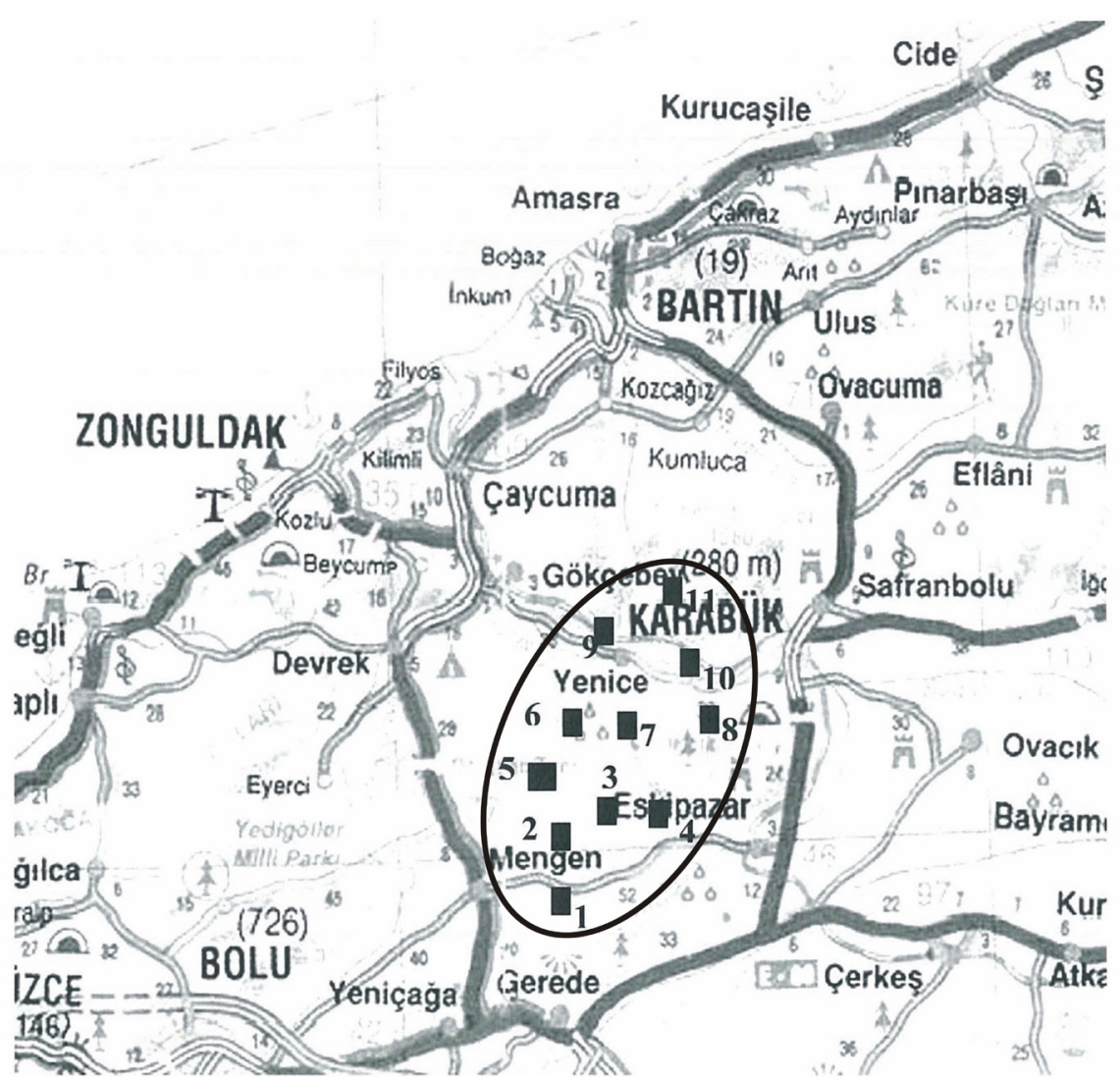

Figure 1. Regional map of the study area.

\section{Lichen material}

P. furfuracea samples were collected from 10 different Pinus species that were located at various distances to the pollution sources (leg., det. Dr. D. Cansaran Duman) (Table 1). Each territory was determined as a station and was numbered from 1 to 10 . The samples collected from a few trees from each station were homogenized before the analysis.

In the laboratory, lichen samples were cleaned from contaminants with the aid of a binocular microscope (Olympus) and consecutive washings with distilled water before DNA isolation.

\section{DNA extraction and RAPD analysis}

DNA extraction from the lichen samples was performed according to the protocol improved for various lichen species by Aras and Cansaran (2006). Concentrations of the extracted DNA samples were measured at $260 \mathrm{~nm}$ and the purity was estimated by measur- 
ing the $260 / 280 \mathrm{~nm}$ absorbance ratio by nanodrop (NanoDrop ND-1000 Spectrophotometer). The DNA concentrations were approximately in the range of $800 \mathrm{ng} / \mu \mathrm{L}$ to $2100 \mathrm{ng} / \mu \mathrm{L}$ and $260 / 280 \mathrm{~nm}$ ratios ranged from 1.76 to 1.91 . The integrity of the DNA samples was also evaluated by agarose gel electrophoresis.

PCR was performed in a reaction volume of $25 \mu \mathrm{L}$ containing $200 \mathrm{ng}$ genomic DNA, $2.5 \mu \mathrm{L} 10 \mathrm{X}$ reaction buffer, $2.5 \mathrm{mM} \mathrm{MgCl}, 20 \mu \mathrm{M}$ dNTPs, $0.2 \mu \mathrm{M}$ primer, $0.5 \mathrm{U}$ Taq polymerase (Promega) and $\mathrm{ddH}_{2} \mathrm{O}$, which was added to the standard volume. The PCR program had an initial cycle of $30 \mathrm{~s}$ at $94^{\circ} \mathrm{C}$ for the denaturation step, followed by 35 cycles of $1 \mathrm{~min}$ at $33^{\circ} \mathrm{C}$ for annealing, $1.45 \mathrm{~min}$ at $72^{\circ} \mathrm{C}$ for extension steps and a final extension step of $8 \mathrm{~min}$ at $72^{\circ} \mathrm{C}$ was also applied. Primer screening for RAPD analysis was performed using 25 primers and 10 of them amplified clear and reproducible bands. Amplified samples and a $100 \mathrm{bp}$ DNA marker were loaded on $1.6 \%$ agarose gels containing $0.5 \mu \mathrm{L} / \mathrm{mL}$ ethidium bromide, and run at $5 \mathrm{~V} / \mathrm{cm}$ for $4 \mathrm{~h}$. Samples were visualized and analyzed under UV light by Gene Genius Bioimaging System, Syngene. The sequences of the 10 decamer primers used in the study are shown in Table 2.

\section{Data analysis for RAPD fingerprints}

Data bands appearing in the control sample are considered the criterion for judgment in the analysis of RAPD (Figure 2). Polymorphism observed in RAPD profiles included the disappearance of a normal band and appearance of a normal band in comparison to RAPD profiles in the control (Atienzar et al., 1999; Liu et al., 2005) and the total number of band changes is given in Table 3 .

\section{Estimation of genomic template stability}

Genomic template stability (GTS) values were also calculated according to results of RAPD analysis. GTS implies a qualitative measure showing the obvious change to the number of RAPD profiles generated by the lichen samples collected from the polluted areas, in relation to profiles obtained from the control lichen sample. GTS \% was calculated as

GTS $=\left(1-\frac{a}{n}\right) \times 100 \%$, where $a$ indicates the RAPD polymorphic profiles in each sample, and $n$ is the number of total bands in the control. Changes in the RAPD patterns were expressed as a decrease in GTS values (Table 4).

\section{RESULTS AND DISCUSSION}

In the current study the genotoxic effects of various environmental pollutants were tested with the samples collected from their natural habitats from the Karabük region. Twentyfive different primers were tested for RAPD analysis (Table 2) and 10 of the primers yielded clear and reproducible bands. The changes in band numbers in the form of appearance and disappearance of the bands were obvious (Table 3) as can be observed in Figure 2.

Among the primers used, Tube A03 showed the highest polymorphism while Tube A02 and Tube A04 showed monomorphic band patterns. The ratio of polymorphism was calculated as the number of polymorphic bands/total bands x 100 (Table 3). According to this calculation, the appearance of a new band (a) or disappearance of an existing band in comparison with 
Table 2. The sequence of the primers used in the study.

\begin{tabular}{ll}
\hline Primer name & Primer sequence $\left(5^{\prime} \rightarrow 3^{\prime}\right)$ \\
\hline TUBE A 01 & CAGGCCCTTC \\
TUBE A02 & TGCCGAGCTG \\
TUBE A03 & AGTCAGCCAC \\
TUBE A04 & AATCGGGCTG \\
B 389 & CGCCCGCAGT \\
OPO 04 & AAGTCCGCTC \\
OPA 13 & CAGCACCCAC \\
OPA 18 & AGGTGACCGT \\
OPB 17 & AGGGAACGAG \\
OPF 05 & CCGAATTCCC \\
\hline
\end{tabular}

Table 3. Changes of total bands in control, polymorphic bands and varied bands in samples.

\begin{tabular}{|c|c|c|c|c|c|c|c|c|c|c|c|c|c|c|c|c|c|c|c|c|c|}
\hline \multirow[t]{2}{*}{ Primer } & \multirow[t]{2}{*}{$\mathrm{C}$} & \multicolumn{2}{|c|}{$\mathrm{S} 1$} & \multicolumn{2}{|l|}{$\mathrm{S} 2$} & \multicolumn{2}{|l|}{$\mathrm{S} 3$} & \multicolumn{2}{|l|}{ S4 } & \multicolumn{2}{|c|}{ S5 } & \multicolumn{2}{|l|}{ S6 } & \multicolumn{2}{|l|}{ S7 } & \multicolumn{2}{|l|}{ S8 } & \multicolumn{2}{|l|}{ S9 } & \multicolumn{2}{|l|}{$\mathrm{S} 10$} \\
\hline & & $\mathrm{a}$ & $\mathrm{b}$ & $\mathrm{a}$ & $\mathrm{b}$ & $\mathrm{a}$ & $\mathrm{b}$ & $\mathrm{a}$ & $\mathrm{b}$ & $\mathrm{A}$ & $\mathrm{b}$ & $\mathrm{a}$ & $\mathrm{b}$ & $\mathrm{a}$ & $\mathrm{b}$ & $\mathrm{a}$ & $\mathrm{b}$ & $\mathrm{a}$ & $\mathrm{b}$ & $\mathrm{a}$ & $\mathrm{b}$ \\
\hline Tube A01 & 5 & 1 & 0 & 0 & 0 & 1 & 0 & 0 & 0 & 1 & 1 & 1 & 0 & 2 & 0 & 1 & 0 & 0 & 0 & 0 & 1 \\
\hline Tube A02 & 5 & 0 & 0 & 0 & 0 & 0 & 0 & 0 & 0 & 0 & 0 & 0 & 0 & 0 & 0 & 0 & 0 & 0 & 0 & 0 & 0 \\
\hline Tube A03 & 8 & 0 & 1 & 0 & 1 & 0 & 0 & 0 & 0 & 0 & 0 & 0 & 1 & 1 & 1 & 2 & 0 & 0 & 1 & 2 & 0 \\
\hline Tube A04 & 4 & 0 & 0 & 0 & 0 & 0 & 0 & 0 & 0 & 0 & 0 & 0 & 0 & 0 & 0 & 0 & 0 & 0 & 2 & 0 & 0 \\
\hline В 389 & 11 & 0 & 0 & 0 & 0 & 0 & 1 & 1 & 0 & 0 & 0 & 2 & 0 & 0 & 0 & 0 & 0 & 3 & 0 & 0 & 0 \\
\hline Opo 04 & 8 & 0 & 0 & 0 & 0 & 0 & 0 & 1 & 0 & 0 & 0 & 0 & 0 & 1 & 1 & 1 & 0 & 0 & 0 & 1 & 0 \\
\hline Opa 13 & 10 & 0 & 1 & 0 & 1 & 0 & 1 & 0 & 1 & 0 & 1 & 0 & 1 & 0 & 0 & 0 & 3 & 0 & 1 & 2 & 1 \\
\hline Opa 18 & 8 & 0 & 0 & 1 & 0 & 0 & 0 & 1 & 0 & 1 & 0 & 0 & 0 & 0 & 0 & 1 & 0 & 1 & 0 & 3 & 0 \\
\hline Opb 17 & 7 & 0 & 0 & 0 & 0 & 0 & 0 & 1 & 0 & 0 & 0 & 1 & 0 & 0 & 2 & 0 & 0 & 1 & 0 & 2 & 0 \\
\hline Opf 05 & 9 & 0 & 0 & 0 & 0 & 0 & 1 & 0 & 0 & 1 & 0 & 0 & 0 & 0 & 0 & 0 & 1 & 0 & 0 & 2 & 0 \\
\hline$a+b$ & & 3 & & 3 & & 4 & & 5 & & 5 & & 6 & & 8 & & 9 & & 9 & & 14 & \\
\hline Primer & TB & & & PB & & & & PR (\%) & & & indi & $\begin{array}{l}\text { nce } \\
\text { aran } \\
\text { tes } p\end{array}$ & $\begin{array}{l}\text { new } \\
\text { of } \\
\text { lym }\end{array}$ & $\begin{array}{l}\text { and } \\
\text { ntrol } \\
\text { phic }\end{array}$ & $\begin{array}{l}\text { ands, } \\
\text { ands. }\end{array}$ & & & & & & \\
\hline Tube A01 & 11 & & & 6 & & & & 54.54 & & & $\mathrm{mp}$ & & & & & & & & & & \\
\hline Tube A02 & 7 & & & 4 & & & & 57.14 & & $\begin{array}{l}\mathrm{T} \\
\mathrm{P}\end{array}$ & $\begin{array}{l}\rightarrow \text { tot } \\
\rightarrow \text { po }\end{array}$ & $\begin{array}{l}\text { ban } \\
\text { morp } \\
\text { morp }\end{array}$ & $\begin{array}{l}\text { ic b } \\
\text { ism }\end{array}$ & & & & & & & & \\
\hline Tube A03 & 14 & & & 9 & & & & 64.28 & & & & & & & & & & & & & \\
\hline Tube A04 & 8 & & & 5 & & & & 62.50 & & & & & & & & & & & & & \\
\hline В 389 & 12 & & & 4 & & & & 33.33 & & & & & & & & & & & & & \\
\hline Opo 04 & 9 & & & 5 & & & & 55.55 & & & & & & & & & & & & & \\
\hline Opa 13 & 16 & & & 10 & & & & 62.50 & & & & & & & & & & & & & \\
\hline Opa 18 & 17 & & & 8 & & & & 47.05 & & & & & & & & & & & & & \\
\hline Opb 17 & 14 & & & 6 & & & & 42.85 & & & & & & & & & & & & & \\
\hline Opf 05 & 12 & & & 4 & & & & 33.33 & & & & & & & & & & & & & \\
\hline
\end{tabular}

$\begin{array}{llllllllllll}\mathrm{C} & \mathrm{M} & 1 & 2 & 3 & 4 & 5 & 6 & 7 & 8 & 9 & 10\end{array}$

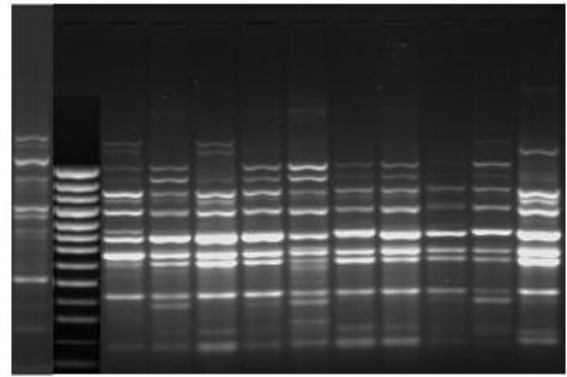

Figure 2. RAPD profiles generated by OPA 18 (5'AGGTGACCGT 3') primer from P. furfuracea exposed to polluted areas around the steel mill in Karabuk. Lane $M=$ molecular weight marker (100 bp. ladder); lane $C=$ control sample. 
control was named as polymorphic. Changes in intensities of the bands were ignored as they appeared in negligible amounts. Samples which were closer to the pollution sources showed considerable polymorphism in RAPD profiles compared to the control sample (Table 3).

In the current study, among 10 stations, Station 1 is close to the pollution sources as it is located near the motorway and railway. On the other hand, Station 10 is closer to the steel milland cement factory than the other stations. Apart from Station 10, there are other stations close to potential pollution sources and it is estimated that these areas also have pollution risk. Stations number 2, 4 and 5 are also close to the motorway. Stations 8 and 9 are the closest stations to the steel mills after station 10 . The Control Station is very close to Station 7 and both of them are located far away from the allocation units. In another study conducted in parallel with the same samples, some of the heavy metal concentrations were determined and the lowest levels of $\mathrm{Mn}, \mathrm{Pb}, \mathrm{Cr}$ were found in sample 3. $\mathrm{Zn}$ and $\mathrm{Fe}$ were also found relatively low amounts in sample 3 (Cansaran-Duman et al., 2009).

Heavy metals are a major component of air pollution and many studies have shown that concentrations of absorbed heavy metal elements in lichen samples rise as they get closer to polluted sites like busy motorways and steel mills and also depending on the exposure time. Pilegaard (1978, 1979), Goyal and Seaward (1981), Gailey et al. (1985), Gailey and Lloyd (1986), and Vestergaad et al. (1986) showed in their studies with various lichen species that $\mathrm{Pb}, \mathrm{Cu}, \mathrm{Cd}, \mathrm{Mn}, \mathrm{Cr}$, and $\mathrm{Ni}$ element concentrations in lichen samples which are close to the iron and steel mills were higher than those far from industrial sites.

Moreover, the differential rate of increase of metal concentration was stated both in samples from transplant studies and in samples exposed to heavy metals for longer periods of time. In the studies where $\mathrm{Pb}$ pollution was investigated, Ward (1989) and Al-Chalabi and Hawker (2000) showed that $\mathrm{Pb}$ pollution gradually increases in the areas close to motorways. Laaksovirta et al. (1976), Král et al. (1989), Máquas et al. (1990), Kapu et al. (1991), Garty et al. (1997), Scerbo et al. (2002), and many other researchers reported similar results in their studies carried out with lichens. The samples located in bags close to motorways or samples collected from the areas close to motorways have considerably higher $\mathrm{Pb}$ concentrations. Furthermore, many studies have been conducted with various types of lichen species including P. furfuracea, showing their capacity to absorb and accumulate atmospheric heavy metals in urban areas (Cansaran-Duman et al., 2009). Bari et al. (2001) found a significant correlation between several heavy metals $(\mathrm{Cd}, \mathrm{Cr}, \mathrm{Cu}, \mathrm{Fe}, \mathrm{Mn}, \mathrm{Ni}, \mathrm{Pb}, \mathrm{Zn})$ accumulated in thalli of the lichen P. furfuracea (L.) Zopf transplanted for 1 year in a rural site in northern Italy. All these studies prove that lichens are suitable tools for monitoring air pollution.

Despite their high tolerance to heavy metals, accumulated and absorbed metals are not totally harmless for lichens. Many studies have been carried out related to the effects of heavy metals on lichens such as chlorophyll degradation, decrease in photosynthesis, increase in the stress hormone-ethylene, decrease in ATP content, and negative effects on the integrity of the membranes (Liu et al., 2005). In addition to their physiological effects, heavy metals can cause DNA mutations, as they are genotoxic agents as well. Several studies focusing on heavy metal genotoxicity showed that those agents may cause chromosome aberrations, double helix damage, and single and double strand breaks (Tsuda and Kato, 1977; Majone and Lewis, 1979; Jacobson and Turner, 1980; Sugiyama et al., 1991; Anastassopoulou, 2003). PCR based fingerprinting methods provide an efficient tool for the investigation of the mutational changes. RAPD analysis can help determine not only the mutational effects of heavy metals but also the 
mutational effects of organic and inorganic genotoxic agents on different organisms (Labra et al., 2003). Fingerprinting methods such as RAPD and AFLP are sensitive, effective, relatively cheap and simple techniques as they can be applied to various organisms directly from their DNA and they help to analyze the whole genome (Savva, 1996, 1998; Conte et al., 1998; Labra et al., 2003; Liu et al., 2005). They are quite useful, especially for pollution studies as they can compare polluted and nonpolluted samples at the same time and in relatively shorter periods (Liu et al., 2005). In the current study, lichen samples both close and far from the pollution sources were compared in order to provide genotoxicity information of mixed pollutants found in the air. The high number of polymorphic bands were observed in the samples taken from areas close to the railways and motorways (sample 1, 4, 5) and also the samples taken from a station near the steel mill (number 10) implies that a significant level of air pollution including an increase in heavy metal contamination is effective in these areas (Figure $1,2)$. In accord, the results of the previous study conducted in parallel which displayed high levels of heavy metal deposition in the same samples confirm the elevated levels of environmental pollution in the area (Cansaran-Duman et al., 2009).

Additionally, the results of genomic template stability ratios (GTS) were calculated (Table 4). GTS implies a qualitative measure reflecting changes in RAPD profiles. GTS related to the level of DNA damage, the efficiency of DNA repair and replication (Atienzar et al., 1999) could explain the appearance and disappearance of bands. The lowest values were obtained in samples no. 10, 9 and 8. Generally in samples no. 8, 9 and 10, the lowest GTS values were obtained which might imply the sensitivity of lichens to genotoxic stressors near the steel mill. Previous studies have also indicated that mutations, chromosomal rearrangements and other DNA lesions could be the reason for the variation in RAPD band patterns. It was demonstrated that changes in RAPD profiles induced by pollution could be regarded as modifications in genomic template stability. Therefore, as stated by Atienzar et al. (2000) "a high level of DNA damage does not necessarily decrease the genomic template stability because DNA repair and replication are inhibited by the high frequency of DNA damage".

\begin{tabular}{|c|c|}
\hline Name of the sample & GTS ratios (\%) \\
\hline S1 & 96.0 \\
\hline S2 & 96.0 \\
\hline S3 & 94.6 \\
\hline S4 & 93.3 \\
\hline S5 & 93.3 \\
\hline S6 & 92.0 \\
\hline S7 & 89.3 \\
\hline S8 & 88.0 \\
\hline S9 & 88.0 \\
\hline S10 & 81.3 \\
\hline
\end{tabular}

As a result, even a one-band change and a slight decrease in GTS might be meaningful in an RAPD assay. It was also indicated that genomic template stability, a qualitative measure of the genotoxic effect, could also be directly compared with variations in other parameters. It has been reported that GTS was more sensitive than soluble protein content in root tips and was at least as sensitive to root growth (Liu et al., 2005).

Labra et al. (2003) compared the sensitivity of DNA marker techniques such as Restriction Fragment Length Polymorphism (RFLP), RAPD and AFLP to the classical genotoxic 
tests like comet and micronucleus assays that were able to detect temporary DNA changes, which, unlike mutations, may not become permanent alterations in DNA.

In conclusion, the RAPD method used in the study provides a qualitative method in which the type of DNA damage can only be speculated. AFLP, on the other hand, might provide more reliable data but still provide a qualitative means of analysis. In order to obtain quantitative data, more specific methods must be developed to analyze the products. Nonetheless, after optimizing the conditions stringently, RAPD analysis can still be used as an investigation tool to detect DNA alterations in environmental toxicology studies. The method also provides an early warning system with a higher sensitivity than the conventional techniques.

The aim of the current study was to show the genotoxic effect of mixed environmental pollutants on organisms under natural conditions. Although the samples in this study were collected from their original localities, which are very close to each other, still some other parameters might be effective for the recorded polymorphism. In this regard, induction of DNA band changes with one kind of a stressor found in air pollution might provide evidence of the genotoxic potential of air pollution. In a previous study, a controlled experiment with one type of heavy metal treatment was also conducted in our laboratory in order to show the effects of a genotoxic agent in a controlled environment (Aras et al., 2010). In the study a clean sample of $P$. furfuracea collected from the Yenice Forest was exposed to various doses of $\mathrm{Pb}$ in different time intervals. Two out of four primers yielded clear and reproducible bands in heavy metal treated samples. Amplification with the primer Tube A01 revealed that the samples which were exposed to $\mathrm{Pb}$ for 18, 24 and $48 \mathrm{~h}$ were different from the other series after the amplification with Tube A01. Although the polymorphism percentages were not calculated in the study obvious band changes were visualized especially 24 and $48 \mathrm{~h}$ after of $\mathrm{Pb}$ treatments. Results of the study displayed that even just one kind of a stressor $(\mathrm{Pb})$ might induce DNA changes in $P$. furfuracea samples in a controlled environment (Aras et al., 2010). Thus, it might become easier to explain the level of polymorphism recorded in the current study when we consider the complexity of the atmospheric environment in which various gases and contaminants exist together.

The Cansaran-Duman et al. (2011) study on genotoxic contamination was monitored by RAPD analyses on Evernia prunastri lichen samples at different polluted sites in Karabük. A clear genotoxic influence is demonstrated in E. prunastri exposed naturally to railways, motorways and steel mills in Karabük. DNA damage assessed by RAPD analyses in E. prunastri near a steel mill in Karabük, Turkey exhibited similar results as the technique used in this study (Cansaran-Duman et al., 2011). The highest values of DNA damage were obtained by both lichen species (E. prunastri and P. furfuracea) exposed naturally to various polluted sites around the steel mill in Karabük. Accordingly at this site, an increase in genotoxic effect was detected compared with the steel mill. Cansaran-Duman et al. (2011) recorded high deterioration of DNA integrity in E. prunastri exposed at the same site in 2005, while data presented here showed medium DNA damage in P. furfuracea exposed at the same location. But, a direct comparison of results may be difficult due to differences in the biology of the employed species, different season and duration of exposure and because of constant alternations in quality and quantity of air pollution. However, the level of the DNA damage measured in P. furfuracea was lower in E. prunastri in the same region. Although these measurements cannot provide detailed data on a variety of specific chemicals or their interactions responsible for genotoxic impact during the investigated period, they are therefore used here only as an indication of polluted status (Stambuk et al., 2009). This may be due to adaptive mechanisms developed in 
lichen species continuously inhabiting polluted environments. Nevertheless, further studies focused especially on the influence of other ecological factors on DNA damage are needed.

Air pollution represents a threat both to the environment and to human health, and it is estimated that millions of tons of toxic pollutants are released into the air each year. Mines, metal foundries, cement factories, power plants, compost factories, waste treatment facilities and busy motorways are the examples of emission sources of genotoxic agents, especially heavy metals like $\mathrm{Cr}, \mathrm{Ni}, \mathrm{Mn}$, and $\mathrm{Pb}$. Furthermore, using coal for heating in cities causes a considerable amount of heavy metal pollution. As a result detection of DNA polymorphism by RAPD analysis could be used as an investigation tool for environmental toxicology after optimizing the conditions stringently. The present study shows the suitability of the lichen samples for the detection of genotoxicity and also provides information about the level of potential genotoxic agents around a steel mill.

\section{ACKNOWLEDGMENTS}

Research partially supported by Ankara University, Management of Scientific Research Projects (under \#2003-0705080).

\section{REFERENCES}

Al-Chalabi AS and Hawker D (2000). Distribution of vehicular lead in roadside soils of major roads of Brisbane, Australia. Water Air Soil Pollut. 118: 299-310.

Anastassopoulou J (2003). Metal-DNA interactions. J. Mol. Struc. 651/653: 19-26.

Aras S and Cansaran D (2006). Isolation of DNA for sequence analysis from herbarium material of some lichen specimens. Turk. J. Bot. 30: 449-453.

Aras S, Kanlitepe Ç, Cansaran-Duman D, Halici MG, et al. (2010). Assessment of air pollution genotoxicity by molecular markers in the exposed samples of Pseudevernia furfuracea (L.) Zopf in the province of Kayseri (Central Anatolia). J. Environ. Monit. 12: 536-543.

Atienzar FA, Conradi M, Evenden AJ, Jha AN, et al. (1999). Qualitative assessment of genotoxicity using random amplified polymorphic DNA: Comparison of genomic template stability with key fitness parameters in Daphnia magna exposed to benzo[a]pyrene. Environ. Toxicol. Chem. 18: 2275-2282.

Atienzar FA, Cordi B, Donkin ME, Evenden AJ, et al. (2000). Comparison of ultraviolet-induced genotoxicity detected by random amplified polymorphic DNA with chlorophyll fluorescence and growth in a marine macroalgae, Palmaria palmata. Aquat. Toxicol. 50: 1-12.

Bargagli R, Brown DH and Nelli L (1995). Metal biomonitoring with mosses: procedures for correcting for soil contamination. Environ. Pollut. 89: 169-175.

Bari A, Rosso A, Minciardi MR, Troiani F, et al. (2001). Analysis of heavy metals in atmospheric particulates in relation to their bioaccumulation in explanted Pseudevernia furfuracea thalli. Environ. Monit. Assess. 69: 205-220.

Belfiore NM and Anderson SL (2001). Effects of contaminants on genetic patterns in aquatic organisms: a review. Mutat. Res. 489: 97-122.

Cansaran-Duman D, Atakol O, Atasoy I, Kahya D, et al. (2009). Heavy metal accumulation in Pseudevernia furfuracea (L.) Zopf from the Karabuk iron-steel factory in Karabuk, Turkey. Z. Naturforsch. C 64: 717-723.

Cansaran-Duman D, Beyaztaş T, Atakol O and Aras S (2011). Assesment of the air pollution genotoxicity by RAPD in Evernia prunastri L. Ach. province of iron-steel factory in Karabük, Turkey. J. Environ. Sci. Chine 23: 1171-1178.

Conte C, Mutti I, Puglisi P, Ferrarini A, et al. (1998). DNA fingerprinting analysis by a PCR based method for monitoring the genotoxic effects of heavy metals pollution. Chemosphere 37: 2739-2749.

Depledge MH (1998). The ecotoxical significance of genotoxicity in marine invertebrates. Mutat. Res. 399: 109-122.

Fernandez JA, Rey A and Carballeira A (2000). An extended study of heavy metal deposition in Galicia (NW Spain) based on moss analysis. Sci. Total Environ. 254: 31-44.

Gailey FAY, Smith GH, Rintoul LJ and Lloyd OL (1985). Metal deposition patterns in central Scotland, as determined by lichen transplants. Environ. Monit. Assess. 5: 291-309. 
Gailey FAY and Lloyd OL (1986). Methodological investigations into low technology monitoring of atmospheric metal pollution: Part 2 - The effects of length of exposure on metal concentrations. Environ. Pollut. 12: 61-74.

Garty J, Kloog N, Wolfson R, Cohen Y, et al. (1997). The influence of air pollution on the concentration of mineral elements, on the spectral reflectance response and on the production of stress-ethylene in the lichen Ramalina duriaei. New Phytol. 137: 587-597.

Goyal R and Seaward MRD (1981). Lichen ecology of the Scunthorpe Heatlands. II. Industrial metal fallout pattern from lichen and soil assays. Lichenologist 13: 289-300.

Jacobson KB and Turner JE (1980). The interaction of cadmium and certain other metal ions with proteins and nucleic acids. Toxicology 16: 1-37.

Jerrett M, Burnett RT, Ma R, Pope CA, III, et al. (2005). Spatial analysis of air pollution and mortality in Los Angeles. Epidemiology 16: 727-736.

Jha AN (2004). Genotoxicological studies in aquatic organisms: an overview. Mutat. Res. 552: 1-17.

Kalpaxis DL, Theos C, Xaplanteri MA, Dinos GP, et al. (2004). Biomonitoring of Gulf of Patras, N. Peloponnesus, Greece. Application of a biomarker suite including evaluation of translation efficiency in Mytilus galloprovincialis cells. Environ. Res. 94: 211-220.

Kapu MM, Ipaye MM, Ega RA, Akanya HO, et al. (1991). Lichens as bioindicators of aerial fallout of heavy metals in Zaria, Nigeria. Bull. Environ. Contam. Toxicol. 47: 413-416.

Král R, Kryzova L and Liska J (1989). Background concentrations of lead and cadmium in the lichen Hypogymnia physodes at different altitudes. Sci. Total Environ. 84: 201-209.

Laaksovirta K, Olkkonen H and Alakuijala P (1976). Observations on the lead content of lichen and bark adjacent to a highway in southern Finland. Environ. Pollut. 11: 247-255.

Labra M, Di Fabio T, Grassi F, Regondi SM, et al. (2003). AFLP analysis as biomarker of exposure to organic and inorganic genotoxic substances in plants. Chemosphere 52: 1183-1188.

Liu W, Li PJ, Qi XM, Zhou QX, et al. (2005). DNA changes in barley (Hordeum vulgare) seedlings induced by cadmium pollution using RAPD analysis. Chemosphere 61: 158-167.

Majone F and Levis AG (1979). Chromosomal aberrations and sister-chromatid exchanges in Chinese hamster cells treated in vitro with hexavalent chromium compounds. Mutat. Res. 67: 231-238.

Máquas C, Kratz W, Sérgio C, Sim-Sim M, et al (1990). The Use of Epiphytes for the Monitoring of Environmental Heavy Metal Pollution in Portugal. In: Environmental Contamination (Barceló J, ed.). Proceeding of the 4th International Conference, Barcelona, 254-256.

Ölmez I, Gulovali MC and Gordon GE (1985). Trace element concentrations in lichens near a coal-fired power plant. Atmosp. Environ. 19: 1663-1669.

Pilegaard K (1978). Airborne metals and $\mathrm{SO}_{2}$ monitored by epiphytic lichens in an industrial area. Environ. Pollut. 17: $81-92$.

Pilegaard K (1979). Heavy metals in bulk precipitation and transplanted Hypogymnia physodes and Dicranoweisia cirrata in the vicinity of a Danish steelworks. Water Air Soil Pollut. 11: 77-91.

Piraino F, Aina R, Palin L, Prato N, et al. (2006). Air quality biomonitoring: assessment of air pollution genotoxicity in the Province of Novara (North Italy) by using Trifolium repens L. and molecular markers. Sci. Total Environ. 372: 350-359.

Savva D (1996). DNA fingerprinting as a biomarker assay in ecotoxicology. Toxicol. Ecotoxicol. News Rev. 3: 110-114.

Savva D (1998). Use of DNA fingerprinting to detect genotoxic effects. Ecotoxicol. Environ. Saf. 41: 103-106.

Scerbo R, Ristori T, Possenti L, Lampugnani L, et al. (2002). Lichen (Xanthoria parietina) biomonitoring of trace element contamination and air quality assessment in Pisa Province (Tuscany, Italy). Sci. Total Environ. 286: 27-40.

Stambuk A, Pavlica M, Vignjevic G, Bolaric B, et al. (2009). Assessment of genotoxicity in polluted freshwaters using caged painter's mussel, Unio pictorum. Ecotoxicology 18: 430-439.

Sugiyama M, Lin XH and Costa M (1991). Protective effect of vitamin E against chromosomal aberrations and mutation induced by sodium chromate in Chinese hamster V79 cells. Mutat. Res. 260: 19-23.

Tsuda H and Kato K (1977). Chromosomal aberrations and morphological transformation in hamster embryonic cells treated with potassium dichromate in vitro. Mutat. Res. 46: 87-94.

Vestergaard NK, Stephansen U, Rasmussen L and Pilegaard K (1986). Airborne heavy metal pollution in the environment of a Danish steel plant. Water Air Soil Pollut. 27: 363-377.

Ward NI (1989). Multielement Contamination of British Motorway Environments. In: Heavy Metals in the Environment (Vernet JP, ed.). Proceeding of the International Conference, Geneva, 279-282. 